Article

\title{
Multi-Extraction and Quality of Protein and Carrageenan from Commercial Spinosum (Eucheuma denticulatum)
}

\author{
Alireza Naseri ${ }^{1}$, Charlotte Jacobsen ${ }^{1, * \mathbb{C}}$, Jimmy J. P. Sejberg ${ }^{2}$, Tommy Ewi Pedersen ${ }^{2}$, \\ Jan Larsen $^{2}$, Karin Meyer Hansen ${ }^{2}$ and Susan L. Holdt ${ }^{1}$ D \\ 1 Research Group for Bioactives-Analysis and Application, The National Food Institute, Technical University \\ of Denmark (DTU Food), Kemitorvet, Building 204, DK-2800 Kgs. Lyngby, Denmark; \\ alireza@food.ku.dk (A.N.); suho@food.dtu.dk (S.L.H.) \\ 2 Innovation, CP Kelco, Ved Banen 16, DK-4623 Lille Skensved, Denmark; jimmy.sejberg@cpkelco.com (J.J.P.S); \\ tommy.ewi.pedersen@gmail.com (T.E.P.); jan.larsen@cpkelco.com (J.L.); \\ KarinMeyer.hansen@cpkelco.com (K.M.H.) \\ * Correspondence: chja@food.dtu.dk
}

Received: 16 June 2020; Accepted: 3 August 2020; Published: 6 August 2020

\begin{abstract}
Seaweeds contain many valuable compounds that can be used in the food industry. Carrageenan is a polysaccharide which has been extracted from seaweed for centuries and is used as a texturizer in food and non-food products. However, seaweeds contain compounds other than carrageenan, such as proteins, which could also be extracted. This extraction should be done without compromising the industrial scale carrageenan extraction yield and quality. This study aimed at up-stream protein extraction from red seaweed Eucheuma denticulatum by using of an optimized enzyme-assisted extraction, including of an aqueous/enzymatic treatment followed by alkaline extraction, and then the commercial carrageenan extraction. The protein extraction efficiency of four enzymes was evaluated including Celluclast ${ }^{\circledR} 1.5 \mathrm{~L}$, Shearzyme ${ }^{\circledR} 500 \mathrm{~L}$, Alcalase ${ }^{\circledR} 2.4 \mathrm{~L} \mathrm{FG}$ and Viscozyme ${ }^{\circledR} \mathrm{L}$ at a concentration of $0.0,0.1,0.2$ and $0.4 \%(w / w)$. To avoid detrimental effects on carrageenan, all the experiments were performed at $\mathrm{pH} 7$ at room temperature. The results showed that $0.2 \% w / w$ Alcalase ${ }^{\circledR}$ or Viscozyme ${ }^{\circledR}$ added individually achieved the highest protein extraction efficiencies (59 and $48 \%$, respectively) at $\mathrm{pH} 7$ and room temperature $(p<0.05)$. Determination of the most common carrageenan quality parameters indicated that using any of these enzymes had no negative effect on the carrageenan yield and quality.
\end{abstract}

Keywords: algae; industrial seaweeds; vegan protein; combined extraction; bioactive compounds; sustainability; bioeconomy; functionality

\section{Introduction}

Seaweeds contain many industrial ingredients, but also other compounds of interest, including bioactive compounds, which can be used in the food industry. Carrageenan is a polysaccharide, which has been extracted from seaweed for centuries and is used as a texturizer in food and non-food products. Eucheuma denticulatum, with the commercial name spinosum, is one of the main red seaweeds used in carrageenan production, and this seaweed constituted almost $20 \%$ of the carrageenan-containing seaweeds harvested worldwide in 2015 [1]. Methods of extracting carrageenan from seaweed are well known, and such methods involve alkaline extraction of seaweed at high temperatures (generally around $100-120^{\circ} \mathrm{C}$ ) [2]. However, the commercially used alkaline extraction of seaweed usually results in a carrageenan product, which also contains other compounds, such as proteins, antioxidants, and pigments [3]. 
It would be advantageous to have a method of preparing carrageenan, where other compounds including bioactive compounds from seaweeds could be extracted as value-added products, without decreasing the carrageenan yield and the functional quality of the carrageenan.

Furthermore, the global demand for protein is increasing and is expected to escalate further in the coming decades-mostly due to population growth, which must be matched by increased food production [4]. There is a good reason to develop new technologies for the industrial extraction of vegan proteins from seaweeds, since some species of seaweed have an interesting amino acid profile close to that of animal protein. For example, the ratio between essential amino acids (EAA) and total amino acids (AA) in Palmaria palmata was $44-53 \%$ while this score for soya and egg protein was 39 and $47 \%$ respectively [5]. The global carrageenan production in 2014 amounted to 60,000 tonnes, with a value of US\$ 626 million in 2014. From these numbers, it can be estimated that the total dried seaweed consumption for this production, was at least 300,000 tonnes per year. The protein content of these types of seaweed are in the range of 4-28\% [6]. If just half of the total amount of protein could be extracted, more than 20,000 tonnes of a new high-value protein product would be obtained per year. [6,7] The variation in protein content in seaweeds used in carrageenan production could be attributed to differences in seasonality, growth conditions in the environment, or source and species of resource [6,8].

Although E. denticulatum with 4-5\% protein content has the lowest level of protein in comparison with other seaweeds such as Palmaria palmata, Furcellaria lumbricalis or Chondrus crispus, it should be considered that the global industrial utilization of this seaweed for carrageenan production was 45000 dry tonnes in 2015 which is equal to $20 \%$ of total harvest. Therefore, large amounts of industrial seaweed are available $[1,6]$. Hence, an improved method of extracting carrageenan from seaweed would be advantageous, and in particular, a method enabling the extraction of proteins and other bioactive compounds in addition to carrageenan, without any detrimental effects on carrageenan yield and quality.

In recent years, varieties of processes for the extraction of protein from various seaweed species have been reported. These processes include enzyme-assisted extraction (EAE) $[7,9,10]$, physical processes [11,12], chemical extraction [13,14], as well as novel techniques such as ultrasound-assisted extraction (UAE) [15,16], pulsed electric field (PEF) extraction [12,17], and microwave-assisted extraction (MAE) [4,18].

Some of these studies evaluated the effect of enzymatic treatment, alkaline pretreatment, and process conditions on viscosity and gel strength of carrageenan; extracted from different red seaweeds commonly used in carrageenan production. As an example, Azevedo et al. (2015) studied the effect of pre-extraction alkali treatment on the chemical structure and gelling properties of extracted hybrid carrageenan from C. crispus and Ahnfeltiopsis devoniensis [19]. The results showed that increasing the $\mathrm{KOH}$ content, and the pre-treatment time improved the gelling properties in both seaweeds [19]. In addition, the effect of process conditions on the viscosity and gel strength of semi-refined carrageenan (SRC), produced from red seaweed Kappaphycus alvarezii was studied by Anisuzzaman et al. in 2014. The experimental results showed that gel viscosity increased with the decrease of cooking time, cooking temperature and potassium hydroxide $(\mathrm{KOH})$ concentration $(\% w / w)$. In contrast, gel strength increased when cooking time, cooking temperature and $\mathrm{KOH}$ concentration $(\% w / w)$ increased. [20]. Moreover, in another study, the development of a high yielding carrageenan extraction method from Eucheuma cottonii using cellulase and the fungi Aspergillus niger was investigated [21]. However, no other studies have dealt with both protein and carrageenan extraction from E. denticulatum, as well as the effects of the protein extraction on the yield and quality of the extracted carrageenan.

The overall aim of this study was to design and develop a method to extract more than one product (multi-extraction), e.g., extraction of both protein and carrageenan, from E. denticulatum (spinosum). The extraction of protein from spinosum upstream the carrageenan extraction was optimized with regard to temperature, $\mathrm{pH}$, the concentration of enzymes, and extraction time. The selected enzymes were in accordance with the previous study, which was successfully carried out on P.palmata [5]. The quality of the extracted protein was evaluated based on the amino acid profile, and the contents of 
essential amino acids (EAA). In addition, the effect of multi-extraction on the yield and quality of the isolated carrageenan (i.e., gel strength, turbidity, and viscosity) was evaluated.

\section{Material and Methods}

\subsection{Seaweed Biomass and Preparation}

CP Kelco (Lille Skensved, Denmark) provided the Eucheuma denticulatum seaweed used in their carrageenan production line. The seaweed biomass was harvested and shipped in semi-dried condition in big pack pallets from the Philippines and Indonesia to CP Kelco. The pallets were stored in a non-insulated warehouse at ambient outdoor temperature. The industrial samples were taken from different batches to obtain representative samples. All seaweed samples were dried at ambient temperature (as is the procedure in industrial-scale carrageenan production), after which the biomass was reduced to $0.5-1 \mathrm{~cm}$ particle size using a cutting mill (SM 2000, Retsch, Haan, Germany) in the lab of DTU Food. The milled seaweed was kept in plastic bags in a freezer at $-20^{\circ} \mathrm{C}$ until used. Dry matter (DM) content for all samples in this study was determined by drying the biomass in an oven at $105^{\circ} \mathrm{C}$ until constant weight.

\subsection{Enzymes and Chemicals}

All enzymes, including a cellulase Celluclast ${ }^{\circledR} 1.5 \mathrm{~L}$, the xylanase Shearzyme ${ }^{\circledR} 500 \mathrm{~L}$, the protease (endo-peptidase) Alcalase ${ }^{\circledR}$ 2.4 L FG, and the multi-enzyme mixture Viscozyme ${ }^{\circledR}$ L which contains a wide range of carbohydrases, including arabinase, cellulase, $\beta$-glucanase, hemicellulase, and xylanase, were provided by Novozymes A/S (Bagsværd, Denmark). All chemicals used in this study were from Merck (St. Louis, IL, USA). All solvents used were HPLC grade and purchased from Lab-Scan (Dublin, Ireland). The standards for amino acids analysis were purchased from Sigma-Aldrich (St. Louis, MO, USA). HPLC grade water was prepared by a Milli-Q ${ }^{\circledR}$ Advantage A10 water deionizing system from Millipore Corporation (Billerica, MA, USA).

\subsection{Aqueous/Enzymatic Extraction}

Semi-dried seaweed samples $(25 \mathrm{~g})$ were weighed in $1 \mathrm{~L}$ Erlenmeyer flasks. In accordance with the selected ratio in Table 1, deionized water was added to each of $1 \mathrm{~L}$ Erlenmeyer flasks. The sample was rehydrated for $1 \mathrm{~h}$, and the enzymes were then added. Carrageenan releases from seaweed by increasing the temperature, and the enzymatic treatment was therefore performed at room temperature $\left(20-22^{\circ} \mathrm{C}\right)$, in order not to obtain simultaneous carrageenan and protein extraction. All treatments were run in triplicates $(n=3)$.

Table 1. Protein extraction conditions (ratio, extraction time and enzymes concentration (on weight basis $(w / w \%))$ and the average extraction efficiency $(\%) \pm$ standard deviations of treated Eucheuma denticulatum seaweed. Different superscripts letters in the same column indicate significant difference at the confidence level of $95 \%(\alpha=0.05 ; n=3)$.

\begin{tabular}{|c|c|c|c|c|}
\hline Number & Ratio (Seaweed: Water) & Extraction Time (h) & $\begin{array}{c}\text { The Concentration of Celluclast }{ }^{\circledR} \\
\text { Plus Shearzyme }{ }^{\circledR}(w / w \%)\end{array}$ & Extraction Efficiency (\%) \\
\hline 1 & $1: 15$ & 4 & 0 & $7.2 \pm 0.04^{\mathrm{d}}$ \\
\hline 2 & $1: 15$ & 4 & 0.1 & $10.9 \pm 0.28^{d}$ \\
\hline 3 & $1: 15$ & 4 & 0.2 & $9.2 \pm 0.29 \mathrm{~d}$ \\
\hline 4 & $1: 15$ & 4 & 0.4 & $12.7 \pm 0.42^{d}$ \\
\hline 5 & $1: 15$ & 6 & 0 & $8.1 \pm 0.78^{d}$ \\
\hline 6 & $1: 15$ & 6 & 0.1 & $9.0 \pm 0.32^{d}$ \\
\hline 7 & $1: 15$ & 6 & 0.2 & $12.3 \pm 0.09^{d}$ \\
\hline 8 & $1: 15$ & 6 & 0.4 & $11.9 \pm 0.29^{d}$ \\
\hline 9 & $1: 15$ & 8 & 0 & $8.8 \pm 0.28^{d}$ \\
\hline 10 & $1: 15$ & 8 & 0.1 & $9.4 \pm 0.32 \mathrm{~d}$ \\
\hline 11 & $1: 15$ & 8 & 0.2 & $14.5 \pm 0.43^{a, b, c}$ \\
\hline 12 & $1: 15$ & 8 & 0.4 & $13.7 \pm 0.42^{\mathrm{d}}$ \\
\hline
\end{tabular}


Table 1. Cont.

\begin{tabular}{|c|c|c|c|c|}
\hline Number & Ratio (Seaweed: Water) & Extraction Time (h) & $\begin{array}{c}\text { The Concentration of Celluclast }{ }^{\circledR} \\
\text { Plus Shearzyme }{ }^{\circledR}(w / w \%)\end{array}$ & Extraction Efficiency (\%) \\
\hline 13 & $1: 20$ & 4 & 0 & $7.4 \pm 0.19^{d}$ \\
\hline 14 & $1: 20$ & 4 & 0.1 & $7.3 \pm 0.18^{\mathrm{d}}$ \\
\hline 15 & $1: 20$ & 4 & 0.2 & $9.9 \pm 0.28^{\mathrm{d}}$ \\
\hline 16 & $1: 20$ & 4 & 0.4 & $12.7 \pm 0.30^{\mathrm{d}}$ \\
\hline 17 & $1: 20$ & 6 & 0 & $10.1 \pm 0.44^{\mathrm{d}}$ \\
\hline 18 & $1: 20$ & 6 & 0.1 & $11.5 \pm 0.31^{d}$ \\
\hline 19 & $1: 20$ & 6 & 0.2 & $15.1 \pm 0.52^{\mathrm{a}, \mathrm{b}}$ \\
\hline 20 & $1: 20$ & 6 & 0.4 & $15.5 \pm 0.11^{\mathrm{a}}$ \\
\hline 21 & $1: 20$ & 8 & 0 & $8.8 \pm 0.41^{\mathrm{d}}$ \\
\hline 22 & $1: 20$ & 8 & 0.1 & $11.6 \pm 0.12^{\mathrm{d}}$ \\
\hline 23 & $1: 20$ & 8 & 0.2 & $12.9 \pm 0.11^{\mathrm{d}}$ \\
\hline 24 & $1: 20$ & 8 & 0.4 & $14.2 \pm 0.04^{b, c}$ \\
\hline 25 & $1: 25$ & 4 & 0 & $8.9 \pm 0.49^{d}$ \\
\hline 26 & $1: 25$ & 4 & 0.1 & $8.9 \pm 1.03^{\mathrm{d}}$ \\
\hline 27 & $1: 25$ & 4 & 0.2 & $12.9 \pm 0.25^{\mathrm{d}}$ \\
\hline 28 & $1: 25$ & 4 & 0.4 & $11.8 \pm 2.03^{d}$ \\
\hline 29 & $1: 25$ & 6 & 0 & $9.3 \pm 0.55^{d}$ \\
\hline 30 & $1: 25$ & 6 & 0.1 & $9.8 \pm 0.64^{\mathrm{d}}$ \\
\hline 31 & $1: 25$ & 6 & 0.2 & $10.7 \pm 0.01^{\mathrm{d}}$ \\
\hline 32 & $1: 25$ & 6 & 0.4 & $12.9 \pm 0.43^{d}$ \\
\hline 33 & $1: 25$ & 8 & 0 & $9.4 \pm 0.59^{d}$ \\
\hline 34 & $1: 25$ & 8 & 0.1 & $10.7 \pm 1.08^{d}$ \\
\hline 35 & $1: 25$ & 8 & 0.2 & $12.1 \pm 0.22 \mathrm{~d}$ \\
\hline 36 & $1: 25$ & 8 & 0.4 & $12.6 \pm 0.73^{d}$ \\
\hline
\end{tabular}

Different letters indicate significant differences $(p<0.05)$.

\subsection{NAC-Assisted Alkaline Extraction}

The conditions for the alkaline extraction were modified from those reported by Harnedy and FitzGerald [22] and were done in accordance with the study by Naseri et al. for the extraction of protein from P. palmata [5]. In summary, after the enzymatic treatment (see Section 2.3), the alkaline extraction was don and repeated three times with a solution containing $1 \mathrm{~g} / \mathrm{L}$ of NAC and $4 \mathrm{~g} / \mathrm{L}$ of $\mathrm{NaOH}$. A laboratory orbital shaker was used at a speed of 120-130 rpm and ambient temperature for $1.5 \mathrm{~h}$. (Figure 1). The liquid fractions recovered were pooled together with the liquid fraction recovered from the enzymatic extraction. The pooled liquid fraction was stored at $4{ }^{\circ} \mathrm{C}$ overnight before precipitation of protein by the addition of acid $(\mathrm{HCl})$.

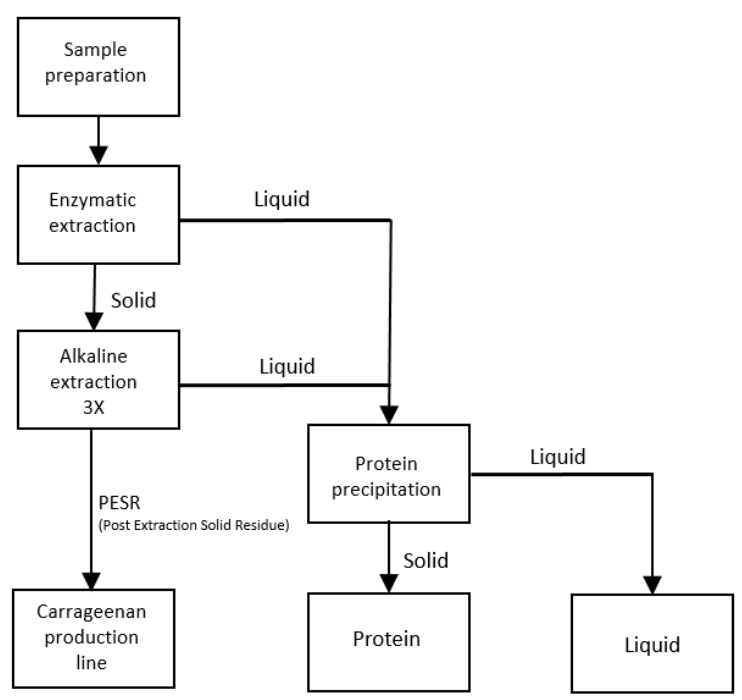

Figure 1. Process flow diagram for a proposed multi-extraction process of seaweed with both enzymatic extraction of proteins, followed by NAC assisted alkaline extraction before the actual industrial utilization of the spinosum seaweed for carrageenan production. 


\subsection{Post-Extraction Solid Residue (PESR)}

At the end of the extraction process, the filter-cakes mentioned above were placed in plastic containers. In order to avoid negative effects of high temperature on protein quality, all filter-cakes were dried in an oven at $40-45^{\circ} \mathrm{C}$. Then, the samples were ground to powder and kept in the freezer at $-20^{\circ} \mathrm{C}$ prior to further analysis.

\subsection{Experimental Plan}

The proposed multi-extraction of proteins and carrageenan from spinosum seaweed is shown in Figure 1. This includes enzymatic treatment, NAC (see explanation above) assisted extraction and protein separation prior to the normal single product carrageenan production/extraction. In order to study and optimize this multi-extraction, the experimental setup consisted of five steps. The first step was to determine the best conditions for temperature, $\mathrm{pH}$, the ratio of seaweed to water and enzyme combination. In accordance with the results reported in the literature [5,23], the ratios of seaweed to water selected were 1:15, 1:20 and 1:25. Enzyme concentrations of $0.0,0.1,0.2$ and $0.4 \% w / w$ were used. All the enzyme treatments were carried out in duplicates for 4,6 or $8 \mathrm{~h}$ at $\mathrm{pH} 7$ to avoid detrimental effect on carrageenan quality.

In the second step, a variety of enzymes were evaluated at different concentrations followed by N-acetyl-L-cysteine (NAC) assisted extraction. NAC, L-cysteine-hydrochloride monohydrate and $\beta$-mercaptoethanol are reducing agents significantly increase the yield of alkaline soluble nitrogen [22]. Therefore, the combination of $\mathrm{NaOH}$ and $\mathrm{NAC}$ as a food-grade reducing agent was selected to increase the extraction of proteins in the current study. In this step, different enzymes were used at the selected optimal condition (Table 1), after which the effect of protein extraction on the yield of carrageenan extraction (step 3) and carrageenan quality (step 4) was evaluated. In the last step, the amino acid profiles for the selected treatments were compared. All treatments were run in triplicates $(n=3)$.

\subsection{Protein Precipitation and Centrifugation}

Protein precipitation was performed by lowering the $\mathrm{pH}$ of the solution to the isoelectric point of the protein (3.5). The $\mathrm{pH}$ of the pooled protein extract was lowered to 3.5 by the addition of aqueous hydrochloric acid (2 M). Subsequently, the mixture was centrifuged at $4400 \mathrm{~g}$ for $15 \mathrm{~min}$ at $4{ }^{\circ} \mathrm{C}$ and then the supernatant and solid residue were separated and stored in the freezer at $-20^{\circ} \mathrm{C}$. The solid fractions were freeze-dried and milled prior to the analysis ( $c f$. above).

\subsection{Total Nitrogen, Protein Content and Extraction Efficiency}

Total nitrogen content was measured by a DUMAS nitrogen/protein analyzer using a fully automated rapid MAX-N exceed (Elementar Analysensysteme GmbH, Langenselbold, Germany). For this purpose, $150-250 \mathrm{mg}$ of dried fractions and 3-4 mL of liquid fractions were fed into the analyser. Protein content was calculated by multiplying the nitrogen content by a conversion factor of 5 [24]. All treatments were run in triplicates $(n=3)$.

The protein extraction efficiency for every treatment was calculated based on the below equation [5]:

$$
\text { Extraction efficiency } \%=\frac{\text { Protein content before extraction- Protein content after extraction }}{\text { Protein content before extraction }} \times 100
$$

To do the calculation faster, the below equation was used:

$$
\text { Extraction efficiency }(\%)=100 \%-\text { Protein recovered in PESR \% }
$$

\subsection{Carrageenan Extraction and Yield}

After protein extraction, the seaweed samples were freeze-dried, milled and passed through a 1 $\mathrm{mm}$ mesh sieve to obtain uniform particle size. The carrageenan was extracted using a water-extraction technique. In brief, the seaweeds were soaked in milli-Q water overnight $(5 \% w / v)$. The $\mathrm{pH}$ of the 
suspension was adjusted ( $\mathrm{pH} 7.5-8.5)$ by $\mathrm{KOH}$ and the carrageenan was extracted at $99^{\circ} \mathrm{C}$ for $1.5 \mathrm{~h}$ in a water bath with shaking. The carrageenan was separated from the seaweed residue by filtration using filter aid and subsequently isolated by precipitation in isopropanol at the ratio of 1:3 (seaweed/alcohol). The samples were freeze-dried, and yields were determined by weighing [25]. All treatments were run in triplicates $(n=3)$.

\subsection{Carrageenan Gel Strength}

The gelling properties of the isolated carrageenan was evaluated, as it would be performed in industry, in a dessert formulation (milk jelly) prepared from whole milk and sugar. The milk jelly ingredients were heated at $80^{\circ} \mathrm{C}$ for $30 \mathrm{~min}$, then filled directly into crystallization dishes. Finally, the gel was allowed to $\mathrm{cool}$ in a $5{ }^{\circ} \mathrm{C}$ water bath for $3-4 \mathrm{~h}$ and the top layer of the gel was then carefully removed using a wire cheese slicer. The gel and breaking strengths were measured with a Stable Micro System (SMS) Texture Analyser-TX.XT2 (Godalming, UK) with a plunger: 0.5 inch diameter; plunger speed: $1 \mathrm{~mm} / \mathrm{s}$; distance: $30 \mathrm{~mm}$. The gel strength was measured at 4,8 and $12 \mathrm{~mm}$ penetration of the gel. The breaking strength was measured at the first peak on the curve. The gel and breaking strengths were calculated as the averages of three measurements.

\subsection{Turbidity of a $1.0 \%$ Solution of Carrageenan}

The turbidity was determined using HACH 2100 N Turbidimeter. Turbidity was measured using a $1.0 \%(w / w)$ aqueous solution of carrageenan obtained in 2.9 which was prepared by the addition of $1.00 \mathrm{~g}$ carrageenan to $100 \mathrm{~mL}$ deionized water.

\subsection{Food Chemicals Codex (FCC) Viscosity}

The viscosity of the $1.5 \%$ aqueous solution of carrageenan was measured at $75{ }^{\circ} \mathrm{C}$ when making FCC-viscosity on a product standardized with sugar, and the amount of weighed material must be corrected to $1.5 \%$ pure material. FCC viscosity was measured at CP Kelco using a LVF viscometer (Brookfield, Middleboro, MA, USA.) fitted with a UL-adapter. The viscosity was measured at $30 \mathrm{rpm}$ for $30 \mathrm{~s}$.

\subsection{Amino Acid Composition}

The amino acid (AA) composition was determined as described by Farvin et al. (2010). To $50 \mathrm{mg}$ dry weight of the sample was added $6 \mathrm{M}$ aqueous hydrochloric acid, and the mixture was heated in the oven at $105{ }^{\circ} \mathrm{C}$ overnight. Following filtration through a $0.2 \mu \mathrm{m}$ filter, derivatization was carried out using the EZ:Faast kit from Phenomenex A/S (Allerød, Denmark). The amino acid composition was determined using LC-MS (Agilent 1100 Series, LC/MSD Trap, Santa Clara, CA, USA) with an EZ:faast $4 \mathrm{u}$ AAA-MS new column $(250 \times 3.0 \mathrm{~mm}$, Phenomenex $)$ as described by Farvin et al. This procedure does, however, not allow for the detection of tryptophan (Trp) and cysteine (Cys) as both amino acids decompose during the acid hydrolysis [26].

\subsection{Statistical Analysis}

Statgraphics Centurion 18 (Statistical Graphics Corp., Rockville, MD, USA) was used for data analysis. Data were expressed as mean \pm standard deviation, corresponding to three experimental replicates $(n=3)$. Firstly, by ANOVA test, multiple sample comparison analysis was performed to identify significant differences between samples. Secondly, mean values were compared using Duncan's test. Differences between means were considered significant at $p<0.05$. 


\section{Results and Discussion}

\subsection{The Optimization of Parameters for Enzymatic Treatment}

In the present study, industrially utilized semi-dried Eucheuma denticulatum (spinosum) containing approximately $50 \%$ water and $3.8 \%$ DM protein was used as a raw material. Carrageenan is sensitive to low $\mathrm{pH}$ and will start to extract at high temperatures. Hence, to avoid detrimental effects on carrageenan quality, all experiments were performed at room temperature $\left(<30{ }^{\circ} \mathrm{C}\right)$ at $\mathrm{pH} \geq 7$. Based on preliminary experiments, a combination of Celluclast ${ }^{\circledR}$ and Shearzyme ${ }^{\circledR}$ was selected.

Table 1 shows the investigated process parameters, i.e., extraction time, seaweed to water ratio, enzyme concentration, and extraction efficiency. Generally, the obtained results show that the protein extraction efficiency after enzymatic extraction was significantly higher when using a 1:20 ratio of seaweed to water, an extraction time of $6 \mathrm{~h}$, and enzyme concentrations of 0.2 or $0.4 \% w / w$. Shorter extraction time also resulted in some degree of protein extraction, but with lower extraction efficiency. The treatment with the number of 11,19, 20 and 24 had the highest extraction efficiencies. However, treatment number 19, which had the ratio 1:20 and was conducted for $6 \mathrm{~h}$ with $0.2 \% w / w$ of each enzyme, was selected as the optimal condition. This result was in accordance with the previous results reported by Naseri et al. in which applied enzyme-assisted extraction was the best among the tested to extract protein from red seaweed Palmaria palmata [5].

\subsection{Different Enzymes for Protein Extraction}

In general, seaweeds proteins are bound by other non-protein components such as polyphenols and polysaccharides within the cell. Furthermore, seaweeds proteins may be found within macro-molecular assemblies or cross-linked through disulphide bonds to polysaccharides $[5,6,22,27,28]$. Some previous studies have demonstrated that applying alkaline solutions for example sodium hydroxide $(\mathrm{NaOH})$ significantly improves the solubility and extraction of highly water-insoluble proteins from seaweeds and microalgae $[5,27,29]$. In addition, food-grade $\mathrm{NaOH}$ is used in the food industry, and as an example, in the extraction of protein-rich ingredients from different plants for example mainly soybean and chickpea. Two other enzymes (Viscozymes ${ }^{\circledR}$, and Alcalase ${ }^{\circledR}$ ) were also tested and compared with the enzymes already tested in step 1 (Celluclast ${ }^{\circledR}$, Shearzyme ${ }^{\circledR}$ ). Furthermore, all these enzymatic extractions were followed by the NAC-assisted alkaline extraction containing $1 \mathrm{~g} / \mathrm{L}$ of NAC and $4 \mathrm{~g} / \mathrm{L}$ of $\mathrm{NaOH}$ to test for possible further optimization. In order to evaluate the efficiency of NAC-assisted alkaline extraction alone, the first treatment was done with no added enzymes resulting in a protein extraction efficiency of $15.7 \%$. When Celluclast ${ }^{\circledR}$ followed by NAC-assisted alkaline extraction was used, the results showed a steady increase from $19.4 \%$ at the concentration of $0.1 \% w / w$ enzyme to $37.9 \%$ for the concentration of $0.4 \% w / w$ enzyme. The results for Shearzyme ${ }^{\circledR}$ were different, with the lowest efficiency of $12.3 \%$ at the concentration of $0.2 \% w / w$, while the highest efficiency was $35.8 \%$ at the lower enzymatic concentration of $0.1 \% w / w$. Moreover, it was noticeable that due to an unexplainable reason, the obtained results for protein extraction efficiency of Shearzyme ${ }^{\circledR}$ at $0.2 \% w / w$ was lower than the treatment with no enzymes added.

The Viscozymes ${ }^{\circledR}$ treatment resulted in a significant increase in extraction efficiency in comparison to Celluclast ${ }^{\circledR}$ and Shearzyme ${ }^{\circledR}$. The highest protein extraction efficiency was $48.5 \%$ at the concentration of $0.2 \% w / w$. Viscozymes ${ }^{\circledR}$ is a multi-enzyme complex containing a wide range of carbohydrases, including arabinose, cellulase, $\beta$-glucanase, hemicellulase, and xylanase, and this most likely explains why it was more efficient than the other carbohydrate degrading enzymes.

In the current study, the protease Alcalase ${ }^{\circledR}$ was selected for testing in comparison with other non-protease enzymes, and the protein extraction efficiency of 59.4\% was the significantly highest efficiency among all the experiments conducted in this study (concentration of $0.2 \%$ and tested at pH 7.0) (Table 2). Applying Alcalase ${ }^{\circledR}$ led to the hydrolysis of peptide bonds that link amino acids together in the polypeptide chain forming the protein, and this is most likely the reason for the significantly improved protein extraction. It has also been reported that the protein extraction efficiency 
could be increased if there was no limitation and pre-defined framework with respect to $\mathrm{pH}$ and temperature $[4,5,23]$. For example, the extraction efficiency for Palmaria palmata could reach up to $90 \%$ by using the combination of Alcalase ${ }^{\circledR}$ and Shearzyme ${ }^{\circledR}$ or Alcalase ${ }^{\circledR}$ and Celluclast ${ }^{\circledR}$ at pH 8 and the concentration of $0.2 \%$ for each one at a temperature of $50{ }^{\circ} \mathrm{C}$ for $14 \mathrm{~h} \mathrm{[5].} \mathrm{However,} \mathrm{as} \mathrm{mentioned}$ before, all experiments of this study were done at room temperature $\left(<30^{\circ} \mathrm{C}\right)$ and at neutral $\mathrm{pH}$ in order to the adverse effect on carrageenan quality and to avoid gelling during the extraction process.

Table 2. Protein extraction efficiency (\%) of the seaweed Eucheuma denticulatum treated with different enzymes followed by NAC-assisted alkaline extraction. Results are given as avearge \pm standard deviation. Different superscripts letters in the same column indicate significant difference at the confidence level of $95 \%(\alpha=0.05 ; n=3)$.

\begin{tabular}{|c|c|}
\hline Samples & Efficiency \% \\
\hline $\begin{array}{l}\text { Only enzymes (Celluclast + Shearzyme }(0.2 \%) \mathrm{pH}=7) \text {-No NAC-assisted alkaline } \\
\text { extraction }\end{array}$ & $15.1 \pm 0.53^{\mathrm{e}, \mathrm{f}}$ \\
\hline No enzymes $\mathrm{pH}=7$ & $15.7 \pm 0.12 \mathrm{e}, \mathrm{f}$ \\
\hline Celluclast $(0.1 \%) \mathrm{pH}=7$ & $19.4 \pm 0.49^{\mathrm{d}, \mathrm{e}, \mathrm{f}}$ \\
\hline Celluclast $(0.2 \%) \mathrm{pH}=7$ & $22.1 \pm 8.89 \mathrm{~d}, \mathrm{e}$ \\
\hline Celluclast $(0.4 \%) \mathrm{pH}=7$ & $37.8 \pm 2.73^{c}$ \\
\hline Shearzyme $(0.1 \%) \mathrm{pH}=7$ & $35.8 \pm 2.91^{\mathrm{c}}$ \\
\hline Shearzyme $(0.2 \%) \mathrm{pH}=7$ & $12.3 \pm 1.34^{\mathrm{f}}$ \\
\hline Shearzyme $(0.4 \%) \mathrm{pH}=7$ & $24.8 \pm 2.78^{\mathrm{d}}$ \\
\hline Viscozymes $(0.1 \%) \mathrm{pH}=7$ & $36.0 \pm 8.14^{\mathrm{c}}$ \\
\hline Viscozymes $(0.2 \%) \mathrm{pH}=7$ & $48.5 \pm 6.67^{b}$ \\
\hline Viscozymes $(0.4 \%) \mathrm{pH}=7$ & $41.8 \pm 2.60^{b, c}$ \\
\hline Celluclast + Shearzyme $(0.1 \%) \mathrm{pH}=7$ & $20.5 \pm 1.88^{\mathrm{d}, \mathrm{e}, \mathrm{f}}$ \\
\hline Celluclast + Shearzyme $(0.2 \%) \mathrm{pH}=7$ & $39.1 \pm 7.39^{c}$ \\
\hline Celluclast + Shearzyme $(0.4 \%) \mathrm{pH}=7$ & $24.8 \pm 2.94^{\mathrm{d}}$ \\
\hline Celluclast + Shearzyme $(0.2 \%) \mathrm{pH}=6$ & $17.7 \pm 3.48^{\mathrm{d}, \mathrm{e}, \mathrm{f}}$ \\
\hline Alcalase $(0.2 \%) \mathrm{pH}=7$ & $59.4 \pm 1.41^{\mathrm{a}}$ \\
\hline
\end{tabular}

Different letters indicate significant differences $(p<0.05)$.

\subsection{Effect of the Protein Extraction Process on the Yield of Carrageenan Extraction}

All the carrageenan extractions were performed based on an optimized method in the lab-scale done by Rhein-Knudsen et al. [25]. In the current study, the yield of isolated carrageenan extraction for the blank sample (with no enzymatic treatment and no NAC-assisted alkaline extraction) was $17.8 \%$, while it increased to $23.8 \%$ when only NAC-assisted alkaline extraction with no enzymatic treatment was tested for protein extraction. Moreover, four different enzymatic treatments were selected to be compared with the blank samples, including Viscozymes $(0.2 \% w / w)$ or Alcalase $(0.2 \%$ $w / w)$ or Celluclast $(0.2 \% w / w)$ plus Shearzyme $(0.2 \% w / w)$ at $\mathrm{pH} 6.0$ and 7.0 followed by NAC-assisted alkaline extraction.

Table 3 shows that Viscozymes $(0.2 \% w / w)$ or Alcalase $(0.2 \% w / w)$ followed by NAC-assisted alkaline extraction had the lowest carrageenan isolation yield with 27.6 and $27.7 \%$, respectively. Celluclast $0.2 \% w / w$ plus Shearzyme $0.2 \% w / w$ followed by NAC-assisted alkaline extraction at $\mathrm{pH} 6.0$, and the same treatment at $\mathrm{pH} 7.0$, had the significantly highest carrageenan yields. The results showed no significant difference between the two samples when treated by only Viscozymes $(0.2 \% w / w)$ or Alcalase combined with NAC-assisted alkaline extraction $(p<0.05)$. 
Table 3. Effect of protein extraction on the yield (\%) of isolated carrageenan of seaweed Eucheuma denticulatum treated with different enzymes followed by NAC-assisted alkaline extraction. Yields are given in average \pm standard deviation. Different superscripts letters in the same column indicate significant difference at the confidence level of $95 \%(\alpha=0.05 ; n=3)$.

\begin{tabular}{cc}
\hline Sample Description & Yield (\%) \\
\hline Blank (No enzymatic treatment, No NAC-assisted alkaline extraction) & $17.8 \pm 0.89^{\mathrm{d}}$ \\
No enzymatic treatment, only NAC-assisted alkaline extraction & $23.8^{\mathrm{d}} \pm 1.62^{\mathrm{c}}$ \\
Celluclast 0.2\% + Shearzyme 0.2\% (pH 6.0) + NAC-assisted alkaline extraction & $31.9 \pm 4.52^{\mathrm{a}, \mathrm{b}}$ \\
Celluclast 0.2\% + Shearzyme 0.2\% (pH 7.0) + NAC-assisted alkaline extraction & $35.5 \pm 2.12^{\mathrm{a}}$ \\
Viscozymes 0.2\% + NAC-assisted alkaline extraction & $27.6 \pm 0.97^{\mathrm{b}, \mathrm{c}}$ \\
Alcalase 0.2\% + NAC-assisted alkaline extraction & $27.8 \pm 3.26^{\mathrm{b}, \mathrm{c}}$ \\
\hline
\end{tabular}

Different letters indicate significant differences $(p<0.05)$.

Varadarajan et al. compared the use of a cellulase from Aspergillus niger, and traditional boiling on the extraction of carrageenan from Eucheuma cottonii [9] They achieved the highest carrageenan yield when using the cellulase ( $45 \%$ by weight) compared to $37 \%$ for fungal treated and $37.5 \%$ for the traditional extraction methods. However, the viscosity of the cellulase-extracted carrageenan was lower than the one extracted by the traditional method. The decrease in viscosity could be explained by the presence of impurities bound to the carrageenan as the cellulase attacks the cell walls in the seaweeds, to release the carrageenan, and thus does not degrade the carrageenan structure itself [21].

\subsection{Effect of the Protein Extraction Process on the Carrageenan Quality}

Table 4 shows the results for gel strength, turbidity, intrinsic viscosity (IV) and Food Chemicals Codex (FCC) viscosity of $1.5 \%$ solution for the isolated carrageenan from the blank and different samples obtained after protein extraction.

The obtained results for gel strength indicated that in comparison with the blank sample, enzymatic treatment with Celluclast ${ }^{\circledR}$ plus Shearzyme ${ }^{\circledR}$ did not change gel strength in 4,8 and $12 \mathrm{~mm}$ whereas the enzymatic treatment with single use of Alcalase ${ }^{\circledR}$ or Viscozymes ${ }^{\circledR}$ increased the gel strength significantly (Table 4). These treatments had the highest protein extraction efficiency; hence, the lowest amount of protein was left in the sample, and therefore, the carrageenan is most likely of higher purity.

The maximum gel strength (breaking strength) and breaking distance for the samples were significantly lower for the combination of Celluclast ${ }^{\circledR}$ plus Shearzyme ${ }^{\circledR}$ at $\mathrm{pH} 6$ and 7 compared to the untreated sample. The same was the case for the sample treated with NAC only. In contrast, there was no significant difference between the samples treated by only Alcalase ${ }^{\circledR}$ or Viscozymes ${ }^{\circledR}$ and the blank sample (Table 4).

Regarding the turbidity, there was a considerable deviation in the obtained results. The highest turbidity was for the blank sample, but it was evident that all the treated samples, especially those treated by the combination of Celluclast ${ }^{\circledR}$ plus Shearzyme ${ }^{\circledR}$, had lower turbidity. The lowest turbidity was observed in the sample treated by Celluclast ${ }^{\circledR} 0.2 \% w / w$ plus Shearzyme ${ }^{\circledR} 0.2 \% w / w$ at $\mathrm{pH} 7$ and followed by NAC-assisted alkaline extraction. Low turbidity is an advantage as it increases the possible applications of the carrageenan product. Therefore, protein extraction could be beneficial for expansion of carrageenan applications in different industries.

Intrinsic viscosity (IV) and FCC-viscosity as two parameters related to the gel viscosity indicated that there was no significant difference between the blank samples, and the samples treated by the combination of Celluclast ${ }^{\circledR}$ plus Shearzyme ${ }^{\circledR}$ or Viscozymes ${ }^{\circledR}$ for protein extraction. There was also no statistical difference between the samples treated by Alcalase ${ }^{\circledR}$, or by only NAC. 
Table 4. Effect of protein extraction of seaweed Eurcheuma denticulatum on the quality of carrageenan gel. Quality is given as averages \pm standard deviations. Different superscript letters in the same column indicate significant difference at the confidence level of $95 \%(\alpha=0.05 ; n=3)$.

\begin{tabular}{|c|c|c|c|c|c|c|c|c|}
\hline Sample Treatments & $\begin{array}{c}\text { Gel Strength } 4 \\
\mathrm{~mm}(\mathrm{~g} / \mathrm{cm})\end{array}$ & $\begin{array}{c}\text { Gel Strength } 8 \\
\mathrm{~mm}(\mathrm{~g} / \mathrm{cm})\end{array}$ & $\begin{array}{l}\text { Gel Strength } 12 \\
\mathrm{~mm}(\mathrm{~g} / \mathrm{cm})\end{array}$ & $\begin{array}{l}\text { Breaking Strength } \\
(\mathrm{g} / \mathrm{cm})\end{array}$ & $\begin{array}{c}\text { Breaking } \\
\text { Distance }(\mathrm{mm})\end{array}$ & $\begin{array}{l}\text { Turbidity } \\
\text { (NTU *) }\end{array}$ & IV & $\begin{array}{c}\text { FCC ** } \\
\text { Viscosity }\end{array}$ \\
\hline $\begin{array}{l}\text { Blank (No enzymatic treatment, No } \\
\text { NAC-assisted alkaline extraction) }\end{array}$ & $8.32 \pm 0.13^{b, c}$ & $15.6 \pm 0.29^{b}$ & $23.6 \pm 0.50^{b, c}$ & $56.5 \pm 3.53^{a}$ & $26.5 \pm 0.22^{a}$ & $62.8 \pm 25.2^{\mathrm{a}}$ & $8.03 \pm 0.22^{a}$ & $249 \pm 24.7^{\mathrm{a}}$ \\
\hline $\begin{array}{l}\text { NO enzymatic treatment, Only } \\
\text { NAC-assisted alkaline extraction, } \mathrm{pH}=7\end{array}$ & $8.09 \pm 0.01^{c}$ & $14.7 \pm 0.14^{\mathrm{c}}$ & $21.5 \pm 0.57^{c}$ & $36.9 \pm 6.71^{b}$ & $22.0 \pm 2.33^{c}$ & $43.8 \pm 11.2^{\mathrm{a}, \mathrm{b}, \mathrm{c}}$ & $7.83 \pm 0.51^{\mathrm{a}}$ & $233 \pm 33.9^{a}$ \\
\hline $\begin{array}{l}\text { Celluclast } 0.2 \%+\text { Shearzyme } 0.2 \%+ \\
\text { NAC-assisted alkaline extraction, } \mathrm{pH}=6\end{array}$ & $8.11 \pm 0.42^{c}$ & $14.9 \pm 0.61^{c}$ & $21.4 \pm 0.01^{\mathrm{c}}$ & $34.6 \pm 1.62^{b}$ & $22.2 \pm 0.92^{c}$ & $33.1 \pm 12.0^{\mathrm{b}, \mathrm{c}}$ & $7.51 \pm 0.31^{\mathrm{a}}$ & $231 \pm 49.5^{\mathrm{a}}$ \\
\hline $\begin{array}{l}\text { Celluclast } 0.2 \%+\text { Shearzyme } 0.2 \%+ \\
\text { NAC-assisted alkaline extraction, } \mathrm{pH}=7\end{array}$ & $8.53 \pm 0.01^{b}$ & $15.7 \pm 0.14^{\mathrm{b}}$ & $22.6 \pm 0.43^{c}$ & $35.2 \pm 1.50^{b}$ & $21.9 \pm 0.11^{c}$ & $29.6 \pm 5.72^{c}$ & $7.59 \pm 0.24^{a}$ & $239 \pm 24.0^{\mathrm{a}}$ \\
\hline $\begin{array}{l}\text { Viscozyme } 0.2 \%+\text { NAC-assisted alkaline } \\
\text { extraction, } \mathrm{pH}=7\end{array}$ & $11.6 \pm 0.20^{\mathrm{a}}$ & $19.1 \pm 0.32^{\mathrm{a}}$ & $25.4 \pm 2.95^{b}$ & $59.0 \pm 1.33^{a}$ & $24.6 \pm 0.60^{a, b}$ & $48.1 \pm 2.14^{\mathrm{a}, \mathrm{b}, \mathrm{c}}$ & $7.89 \pm 0.02^{\mathrm{a}}$ & $222 \pm 2.1^{\mathrm{a}}$ \\
\hline $\begin{array}{l}\text { Alcalase } 0.2 \%+\text { NAC-assisted alkaline } \\
\text { extraction, } \mathrm{pH}=7\end{array}$ & $11.7 \pm 0.31^{\mathrm{a}}$ & $19.4 \pm 0.62^{a}$ & $28.3 \pm 1.52^{a}$ & $59.1 \pm 6.41^{\mathrm{a}}$ & $24.5 \pm 0.80^{\mathrm{b}}$ & $54.2 \pm 18.0^{\mathrm{a}, \mathrm{b}}$ & $7.48 \pm 0.20^{a}$ & $218 \pm 14.8^{\mathrm{a}}$ \\
\hline
\end{tabular}

NTU: Nephelometric Turbidity Unit, ${ }^{* *}$ FCC: Food Chemicals Codex. Different letters indicate significant differences $(p<0.05)$. 
In summary, the obtained results in the present study indicate that Alcalase ${ }^{\circledR}$ at $0.2 \% w / w$ and $\mathrm{pH}$ 7 or Viscozymes ${ }^{\circledR}$ at $0.2 \% w / w$ and $\mathrm{pH} 7$ are the optimal treatment to extract protein from spinosum. As mentioned before, the highest extraction efficiencies were for Alcalase ${ }^{\circledR}$ at $0.2 \% w / w$ and $\mathrm{pH} 7$, which led to a protein extraction efficiency of $59.4 \%$ and for Viscozymes ${ }^{\circledR}$ at $0.2 \% w / w$ and $\mathrm{pH} 7$, the extraction efficiency was $48.5 \%$. It was obvious that in comparison with the Viscozymes ${ }^{\circledR}$, the use of Alcalase ${ }^{\circledR}$ will produce proteins/peptides with low molecular weight. Moreover, although the carrageenan yield for the combination of Celluclast ${ }^{\circledR}$ plus Shearzyme ${ }^{\circledR}$ was higher than when Viscozymes ${ }^{\circledR}$ or Alcalase ${ }^{\circledR}$ were used, the gel quality and in particular, the maximum gel strength (breaking strength) was lower for the combination of Celluclast ${ }^{\circledR}$ plus Shearzyme ${ }^{\circledR}$ compared to Viscozymes ${ }^{\circledR}$ or Alcalase ${ }^{\circledR}$. The results in Table 4 showed that by using Celluclast ${ }^{\circledR}$ plus Shearzyme ${ }^{\circledR}$, there was a negative effect on breaking strength compared to the blank sample. This was in compliance with the study performed by Varadarajan et al. (2009) [21].

Therefore, it could be concluded that using Alcalase ${ }^{\circledR}$ at $0.2 \% w / w$ and $\mathrm{pH} 7$ or Viscozymes ${ }^{\circledR}$ at $0.2 \% w / w$ and $\mathrm{pH} 7$ gave the higher protein extraction efficiency with no detrimental effects on carrageenan quality.

\subsection{Comparison of Amino Acid Profiles}

In the current study, the amino acid profile for the protein extracted by isoelectric precipitation at $\mathrm{pH} 3.5$ for three different treatments were analyzed and compared, including Viscozymes ${ }^{\circledR} 0.2 \% w / w$ or Alcalase ${ }^{\circledR} 0.2 \% w / w$ or the combination of Celluclast ${ }^{\circledR} 0.2 \% w / w$ plus Shearzyme ${ }^{\circledR} 0.2 \% w / w$ which were followed by NAC-assisted alkaline extraction at $\mathrm{pH}$ 7. The reason for selecting these samples was in order to compare the sample with the highest carrageenan extraction yield with the samples with the highest protein extraction efficiencies.

The obtained results showed that protein extracted from the sample treated by the combination of Celluclast ${ }^{\circledR} 0.2 \% w / w$ and Shearzyme ${ }^{\circledR} 0.2 \% w / w$ had the highest amount of total amino acids with $50.8 \mathrm{mg} / \mathrm{g}$ DM. This was due to higher level of glutamic acid, aspartic acid, arginine and cysteine when compared to the protein extracted from the samples treated by Viscozymes ${ }^{\circledR}$ or Alcalase ${ }^{\circledR}$. The protein extracted from samples treated by Viscozymes ${ }^{\circledR} 0.2 \% w / w$ or Alcalase ${ }^{\circledR} 0.2 \% w / w$ had 36.2 and 25.5 $\mathrm{mg} / \mathrm{g}$ DM, respectively (Table 5). The amino acids of highest amount were glutamic acid, aspartic acid, cystine, leucine, alanine, and valine. In addition, in the sample treated with Viscozymes ${ }^{\circledR}$, the lysine content was higher than for the other treatments. However, it was noticeable that arginine was not detectable in the samples treated with Viscozymes ${ }^{\circledR}$ or Alcalase ${ }^{\circledR}$.

In comparison with the previous results obtained by the authors of this study with red seaweed Palmaria palmata, a protein extracted from Euchema denticulatum had a lower value of total amino acid $\left(\sum \mathrm{AA}\right)$ and total essential amino acids ( $\left.\sum E A \mathrm{~A}\right)$ while the value for the ratio of EAA/AA was higher in protein extracted from E. denticulatum. The ratio was $27-42 \%$ for P. palmata while it was $46-54 \%$ for $E$. denticulatum [5]. The main reason could be due to the difference between the protein content of these two seaweeds.

The EAA/AA ratio of $46-54 \%$ of the protein of the E. denticulatum pellets in this experiment is in the same range as $48 \%$ EAA/AA in beef as a model organism for protein requirements, and the $47 \%$ EAA/AA in soybean $[18,19]$. The EEA/AA ratios calculated for beef and soybean were based on data for EEA and total protein content from Damodaran et al. [19]. In our calculation we have assumed that the protein content is equal to the sum of all amino acids. The branched chained amino acids (BCAA) are getting increasing attention, especially in fitness and body builder environments, since the leucine, isoleucine and valine are non-polar EAA that account for $35 \%$ of the EAA in the human muscles. The BCAA/AA ratio of the E. denticulatum pellets are $12-19 \%$ and therefore BCAA constitute a relative large part of the AA, which could make the product interesting for e.g., sport drinks and bars. However, it should be mentioned that protein content of beef and soybean is 18 and $40 \%$ respectively [19], compared to the $2.5-5.1 \%$ of the E. denticulatum pellets. 
Table 5. Amino acid composition (mg amino acid/g DM), total essential amino acid content ( $\sum$ EAA), the essential amino acid ratio (EAA/AA) of the untreated samples of Eucheuma denticulatum seaweed, and extracted protein (pellet) obtained from the different selected enzymes used. The numbers are given as averages \pm standard deviations of triplicates $(n=3)$.

\begin{tabular}{|c|c|c|c|c|}
\hline \multirow[t]{2}{*}{ Amino Acid } & \multirow[t]{2}{*}{$\begin{array}{c}\text { Untreated } \\
\text { Seaweed }\end{array}$} & \multirow{2}{*}{$\begin{array}{c}\text { Viscozyme }^{\circledR} \mathrm{L} \\
\text { Pellet }\end{array}$} & \multirow{2}{*}{$\begin{array}{c}\text { Alcalase }^{\circledR} 2.4 \mathrm{FL} \\
\text { Pellet }\end{array}$} & \multirow{2}{*}{$\begin{array}{c}\text { Celluclast }^{\circledR} 1.5 \mathrm{~L}+ \\
\text { Shearzyme }^{\circledR} 500 \mathrm{~L} \\
\text { Pellet }\end{array}$} \\
\hline & & & & \\
\hline LYS $^{(1)}$ & $1.12 \pm 0.04$ & $2.26 \pm 0.01$ & $1.18 \pm 0.20$ & $1.99 \pm 0.12$ \\
\hline ALA & $1.01 \pm 0.08$ & $2.29 \pm 0.62$ & $1.47 \pm 0.02$ & $3.00 \pm 0.48$ \\
\hline ARG & $0.64 \pm 0.01$ & n.d. & n.d. & $4.74 \pm 0.23$ \\
\hline$C-C^{(1)}$ & n.d & $4.49 \pm 1.03$ & $6.00 \pm 0.84$ & $4.80 \pm 0.06$ \\
\hline $\operatorname{MET}^{(1)}$ & $0.41 \pm 0.03$ & $1.00 \pm 0.16$ & $0.61 \pm 0.05$ & $1.27 \pm 0.01$ \\
\hline LEU (1) & $1.99 \pm 0.27$ & $2.64 \pm 0.26$ & $1.43 \pm 0.01$ & $3.35 \pm 0.26$ \\
\hline TYR ${ }^{(1)}$ & $0.43 \pm 0.09$ & $1.18 \pm 0.12$ & $0.73 \pm 0.05$ & $1.31 \pm 0.07$ \\
\hline PHE ${ }^{(1)}$ & $1.92 \pm 0.07$ & $2.08 \pm 0.01$ & $1.14 \pm 0.10$ & $2.59 \pm 0.06$ \\
\hline PRO & $0.67 \pm 0.05$ & $1.48 \pm 0.25$ & $0.71 \pm 0.04$ & $1.93 \pm 0.11$ \\
\hline $\mathrm{THR}^{(1)}$ & $2.37 \pm 0.04$ & $1.14 \pm 0.21$ & $0.56 \pm 0.04$ & $1.56 \pm 0.42$ \\
\hline ASP & $2.62 \pm 0.23$ & $3.38 \pm 1.04$ & $2.44 \pm 0.13$ & $5.06 \pm 0.93$ \\
\hline SER & $1.48 \pm 0.01$ & $0.99 \pm 0.28$ & $0.57 \pm 0.06$ & $1.49 \pm 0.31$ \\
\hline HYP & n.d. & n.d. & n.d. & n.d. \\
\hline GLU & $2.64 \pm 0.19$ & $6.09 \pm 2.25$ & $4.68 \pm 0.19$ & $7.68 \pm 1.73$ \\
\hline $\mathrm{VAL}^{(1)}$ & n.d & $2.55 \pm 0.26$ & $1.10 \pm 0.08$ & $3.79 \pm 0.89$ \\
\hline HIS $^{(1)}$ & $0.25 \pm 0.03$ & $0.55 \pm 0.00$ & $0.33 \pm 0.07$ & $0.62 \pm 0.01$ \\
\hline $\operatorname{ILE}^{(1)}$ & $1.08 \pm 0.12$ & $1.64 \pm 0.03$ & $0.57 \pm 0.07$ & $2.15 \pm 0.18$ \\
\hline GLY & $0.89 \pm 0.74$ & $2.42 \pm 0.59$ & $1.97 \pm 0.05$ & $3.49 \pm 0.42$ \\
\hline$\sum \mathrm{AA}$ & 19.5 & 36.2 & 25.5 & 50.8 \\
\hline$\sum \mathrm{EAA}$ & 9.57 & 19.53 & 13.65 & 23.43 \\
\hline$\overline{\mathrm{EAA}} / \mathrm{AA}$ & 0.49 & 0.54 & 0.54 & 0.46 \\
\hline
\end{tabular}

(1) Essential amino acids for human nutrition. n.d. means not detected.

\section{Conclusions and Future Perspectives}

The present study successfully showed that it is possible to extract protein from Eucheuma denticulatum, in a multi-extraction setup, adding a new possible future protein resource with amino acid profiles comparable to meat (beef) and whey proteins, and further utilization going towards 'no waste' of our industrial resources. The best enzymes were Alcalase ${ }^{\circledR}$ or Viscozymes ${ }^{\circledR}$ at $0.2 \%$ $w / w$, and the maximum efficiency was increased by up to $60 \%$ of protein for Alcalase ${ }^{\circledR}$. The present study furthermore demonstrated that the protein extraction process did not have a detrimental effect on the isolated carrageenan in the downstream carrageenan processing. For some parameters, the carrageenan behaved better than carrageenan extracted without the pre-extraction of protein. However, further investigation is needed to evaluate the bioactivity of both proteins and carrageenan before and after extraction.

Author Contributions: A.N., C.J., J.J.P.S., T.E.P., K.M.H., J.L., and S.L.H. contributed to conceiving the experiments, A.N., C.J., J.J.P.S. and S.L.H. planned the experiments. A.N. and J.J.P.S. carried out the experiments, analyzed the data, and A.N. wrote the main draft of the manuscript. All authors read and revised the paper and approved the final manuscript.

Funding: This research received funding from GUDP (Green Development and Demonstration Programme) with the journal number 34009-15-1029 as a part of the VALSEA project.

Acknowledgments: The authors wish to acknowledge Inge Holmberg (DTU Food), Helle Bech Olsen (CP Kelco), and Mohammad Amin Mohammadifar (DTU Food) for their technical assistance. Furthermore, we thank Novozymes A/S (Bagsværd, Denmark) for kindly providing all tested enzymes.

Conflicts of Interest: The authors declare no financial or other conflicts of interest. 


\section{References}

1. Qin, Y. Bioactive Seaweeds for Food Applications; Elsevier Ltd.: Eastbourne, UK, 2018.

2. Torres, M.D.; Flórez-Fernández, N.; Domínguez, H. Integral utilization of red seaweed for bioactive production. Mar. Drugs 2019, 17, 314. [CrossRef] [PubMed]

3. Imeson, A.P. Carrageenan and furcellaran. In Handbook of Hydrocolloids; Phillips, G.O., Williams, P.A., Eds.; Woodhead Publishing Limited: Cambridge, UK, 2009; pp. 164-185. ISBN 9781845695873.

4. Bleakley, S.; Hayes, M. Algal Proteins: Extraction, Application, and Challenges Concerning Production. Foods 2017, 6, 33. [CrossRef] [PubMed]

5. Naseri, A.; Marinho, G.S.; Holdt, S.L.; Bartela, J.M.; Jacobsen, C. Enzyme-assisted extraction and characterization of protein from red seaweed Palmaria palmata. Algal Res. 2020, 47, 101849. [CrossRef]

6. Naseri, A.; Holdt, S.L.; Jacobsen, C. Biochemical and Nutritional Composition of Industrial Red Seaweed Used in Carrageenan Production. J. Aquat. Food Prod. Technol. 2019, 28, 967-973. [CrossRef]

7. Rhein-Knudsen, N.; Ale, M.T.; Meyer, A.S. Seaweed hydrocolloid production: An update on enzyme assisted extraction and modification technologies. Mar. Drugs 2015, 13, 3340-3359. [CrossRef] [PubMed]

8. Dawczynski, C.; Schubert, R.; Jahreis, G. Amino acids, fatty acids, and dietary fibre in edible seaweed products. Food Chem. 2007, 103, 891-899. [CrossRef]

9. Kadam, S.U.; Álvarez, C.; Tiwari, B.K.; O’Donnell, C.P. Extraction of biomolecules from seaweeds. In Seaweed Sustainability: Food and Non-Food Applications; Elsevier Inc.: Amsterdam, The Netherlands, 2015; ISBN 9780124199583.

10. Blanco-Pascual, N.; Alemán, A.; Gómez-Guillén, M.C.; Montero, M.P. Enzyme-assisted extraction of k/t-hybrid carrageenan from Mastocarpus stellatus for obtaining bioactive ingredients and their application for edible active film development. Food Funct. 2014, 5, 319-329. [CrossRef]

11. Barba, F.J.; Grimi, N.; Vorobiev, E. New Approaches for the Use of Non-conventional Cell Disruption Technologies to Extract Potential Food Additives and Nutraceuticals from Microalgae. Food Eng. Rev. 2014, 7, 45-62. [CrossRef]

12. Fleurence, J. Seaweed proteins. In Proteins in Food Processing; Elsevier Science: Amsterdam, The Netherlands, 2004; pp. 197-213, ISBN 0849325366.

13. Kadam, S.U.; Álvarez, C.; Tiwari, B.K.; O’Donnell, C.P. Extraction and characterization of protein from Irish brown seaweed Ascophyllum nodosum. Food Res. Int. 2017, 99, 1021-1027. [CrossRef]

14. Kulshreshtha, G.; Burlot, A.S.; Marty, C.; Critchley, A.; Hafting, J.; Bedoux, G.; Bourgougnon, N.; Prithiviraj, B. Enzyme-assisted extraction of bioactive material from Chondrus crispus and codium fragile and its effect on Herpes simplex virus (HSV-1). Mar. Drugs 2015, 13, 558-580. [CrossRef]

15. Chemat, F.; Zill-e-Huma; Khan, M.K. Applications of ultrasound in food technology: Processing, preservation and extraction. Ultrason. Sonochem. 2011, 18, 813-835. [CrossRef] [PubMed]

16. Topuz, O.K.; Gokoglu, N.; Yerlikaya, P.; Ucak, I.; Gumus, B. Optimization of Antioxidant Activity and Phenolic Compound Extraction Conditions from Red Seaweed (Laurencia obtuse). J. Aquat. Food Prod. Technol. 2016, 25, 414-422. [CrossRef]

17. Joannes, C.; Sipaut, C.S.; Dayou, J.; Md.Yasir, S.; Mansa, R.F. The Potential of Using Pulsed Electric Field (PEF) Technology as the Cell Disruption Method to Extract Lipid from Microalgae for Biodiesel Production. Int. J. Renew. Energy Res. 2015, 5, 598-621.

18. Kadam, S.U.; Tiwari, B.K.; O'Donnell, C.P. Application of novel extraction technologies for bioactives from marine algae. J. Agric. Food Chem. 2013, 61, 4667-4675. [CrossRef] [PubMed]

19. Azevedo, G.; Torres, M.D.; Sousa-Pinto, I.; Hilliou, L. Effect of pre-extraction alkali treatment on the chemical structure and gelling properties of extracted hybrid carrageenan from Chondrus crispus and Ahnfeltiopsis devoniensis. Food Hydrocoll. 2015, 50, 150-158. [CrossRef]

20. Anisuzzaman, S.M.; Bono, A.; Ding, O.W. Effect of process conditions on the gel viscosity and gel strength of semi-refined carrageenan (SRC) produced from seaweed (Kappaphycus alvarezii). J. King Saud Univ. Eng. Sci. 2014, 26, 3-9.

21. Varadarajan, S.A.; Ramli, N.; Ariff, A.; Said, M.; Yasir, S.M. Development of high yielding carragenan extraction method from Eucheuma Cotonii using cellulase and Aspergillus niger. In Proceedings of Prosiding Seminar Kimia Bersama UKM-ITB VIII9, Bangi, Malaysia, 9-11 June 2009; pp. 461-469. 
22. Harnedy, P.A.; FitzGerald, R.J. Extraction of protein from the macroalga Palmaria palmata. LWT Food Sci. Technol. 2013, 51, 375-382. [CrossRef]

23. Bjarnadóttir, M.; Aðalbjörnsson, B.V.; Nilsson, A.; Slizyte, R.; Roleda, M.Y.; Hreggviðsson, G.Ó.; Friðjónsson, Ó.H.; Jónsdóttir, R. Palmaria palmata as an alternative protein source: Enzymatic protein extraction, amino acid composition, and nitrogen-to-protein conversion factor. J. Appl. Phycol. 2018, 30, 2061-2070. [CrossRef]

24. Angell, A.R.; Mata, L.; de Nys, R.; Paul, N.A. The protein content of seaweeds: A universal nitrogen-to-protein conversion factor of five. J. Appl. Phycol. 2016, 28, 511-524. [CrossRef]

25. Rhein-Knudsen, N.; Ale, M.T.; Ajalloueian, F.; Yu, L.; Meyer, A.S. Rheological properties of agar and carrageenan from Ghanaian red seaweeds. Food Hydrocoll. 2017, 63, 50-58. [CrossRef]

26. Sabeena Farvin, K.H.; Baron, C.P.; Nielsen, N.S.; Jacobsen, C. Antioxidant activity of yoghurt peptides: Part 1-in vitro assays and evaluation in $\omega-3$ enriched milk. Food Chem. 2010, 123, 1081-1089. [CrossRef]

27. Amano, H.; Noda, H. Proteins of Protoplasts from Red Alga Porphyra yezoensis. Nippon Suisan Gakkaishi 1990, 56, 1859-1864. [CrossRef]

28. Miranda, C.F. Screening of Ionic Liquids for the Extraction of Proteins from the Macroalga Ulva Lactuca Aiming at an Integrated Biorefinery Approach. Master's Thesis, Instituto Superior Técnico, Lisboa, Portugal, 2017.

29. Lourenço, S.O.; Barbarino, E.; De-Paula, J.C.; Pereira, L.O.D.S.; Lanfer Marquez, U.M. Amino acid composition, protein content adn calculation of nitrogen-to-protein conversion factors for 19 tropical seaweeds. Phycol. Res. 2002, 50, 233-241. [CrossRef]

(C) 2020 by the authors. Licensee MDPI, Basel, Switzerland. This article is an open access article distributed under the terms and conditions of the Creative Commons Attribution (CC BY) license (http://creativecommons.org/licenses/by/4.0/). 